\title{
TITLE:
}

\section{The Intertidal Biota of Volcanic Yankich Island (Middle Kuril Islands)}

$\operatorname{AUTHOR}(\mathrm{S})$ :

Kussakin, Oleg G.; Kostina, Elena E.

\section{CITATION:}

Kussakin, Oleg G.... [et al]. The Intertidal Biota of Volcanic Yankich Island (Middle Kuril Islands). PUBLICATIONS OF THE SETO MARINE BIOLOGICAL LABORATORY 1996, 37(3-6): 201-225

ISSUE DATE:

1996-12-25

URL:

http://hdl.handle.net/2433/176267

RIGHT: 


\title{
The Intertidal Biota of Volcanic Yankich Island (Middle Kuril Islands)
}

\author{
Oleg G. Kussakin and Elena E. Kostina \\ Institute of Marine Biology, Academy of Sciences of Russia, \\ Vladivostok 690041, Russia
}

\begin{abstract}
A description of the intertidal biota of volcanic Yankich Island (Ushishir Islands, Kuril Islands) is given. The species composition and vertical distribution pattern of the intertidal communities at various localities are described in relation to environmental factors, such as nature of the substrate, surf conditions and volcanic vent water. The macrobenthos is poor in the areas directly influenced by high temperature $\left(20-40^{\circ} \mathrm{C}\right)$ and high sulphur content. There are no marked changes in the intertidal communities in the areas of volcanic springs that are characterised by temperature below $10^{\circ} \mathrm{C}$ and by the absence of sulphur compounds. In general, the species composition and distribution of the intertidal biota are ordinary for the intertidal zone of the middle Kuril Islands. But there are departures from the typical zonation of the intertidal biota. Also, mass populations of Balanus crenatus appear.
\end{abstract}

Key words: Kuril Islands, intertidal, macrobenthos, volcanic springs

\section{Introduction}

The purpose of this report is to describe the intertidal biota of Yankich Island, a volcanic island in the Ushishir Islands of the middle Kuril Islands. This island is influenced by wave action of various intensities and gaso-hydrothermal activity.

The Ushishir Islands are a group of two small volcanic islands, Yankich Island and its smaller neighbour Reponkich Island. They are situated nearly in the middle of the Kuril Islands chain between Ketoy Island and Rashua Island (Fig. 1) and represent the summits of Ushishir Volcano that became partly submerged several (probably 10) thousand years ago (Gavrilenko et al., 1989). The Ushishir Islands lie at $47^{\circ} 30^{\prime} \mathrm{N}$ and the cold currents running along the middle Kuril Islands lower the sea temperature so much $\left(3-4^{\circ} \mathrm{C}\right.$ in August) that the summer hydrographic conditions correspond to those in the Bering Strait. Tides are irregularly diurnal, with the maximum range of fluctuation of sea level about $2.1 \mathrm{~m}$.

Yankich Island reaches an altitude of $401 \mathrm{~m}$ and its coastline consists mainly of intrusive igneous rocks, forming tall, abrupt cliffs. On the south, Kraternaya Bight cut deeply into the island. This bight is a caldera, a submerged crater connected with the open sea by a long, narrow and shallow passage. At the mouth of the passage lie five stony reefs and sandbanks that separate the bight from the open sea, and a shallow channel which is about $0.2-0.3 \mathrm{~m}$ deep at the lowest low water.

The open craggy coast of the Ushishir Islands is subjected to strong wave action. The wave action is reduced by stony reefs; therefore, in Kraternaya Bight the water is usually calm without surf.

The waters around the Ushishir Islands are usually homogenous and rich in nutrients $(\mathrm{N}-$ $\mathrm{NO}_{3}$ to $30 \mu \mathrm{M}, \mathrm{P}-\mathrm{PO}_{4}$ to $\left.2 \mu \mathrm{M}\right)$. Chlorophyll $a$ concentrations are about $0.2 \mathrm{mg} \mathrm{m} \mathrm{m}^{-3}$ or less (Tarasov et al., 1990).

The Ushishir Islands and especially Kraternaya Bight were intensively investigated in 1985-1992 by expeditions of the Institute of Marine Biology, Vladivostok, headed by V. Tarasov. The results of this survey concerning the marine ecosystem of the caldera of 
Kraternaya Bight have been published in many papers (e.g., in English, Tarasov et al., 1990; Zhirmunsky \& Tarasov, 1990). But as for the intertidal biota, these publications only briefly noted observations on barnacles and littorinids.

The present report is based on observations made during short visits to Yankich Island in June-July, 1988, by E. Kostina and in August-September, 1992, by O. Kussakin. Field trips were made along the southern coast of the island and all around Kraternaya Bight in order

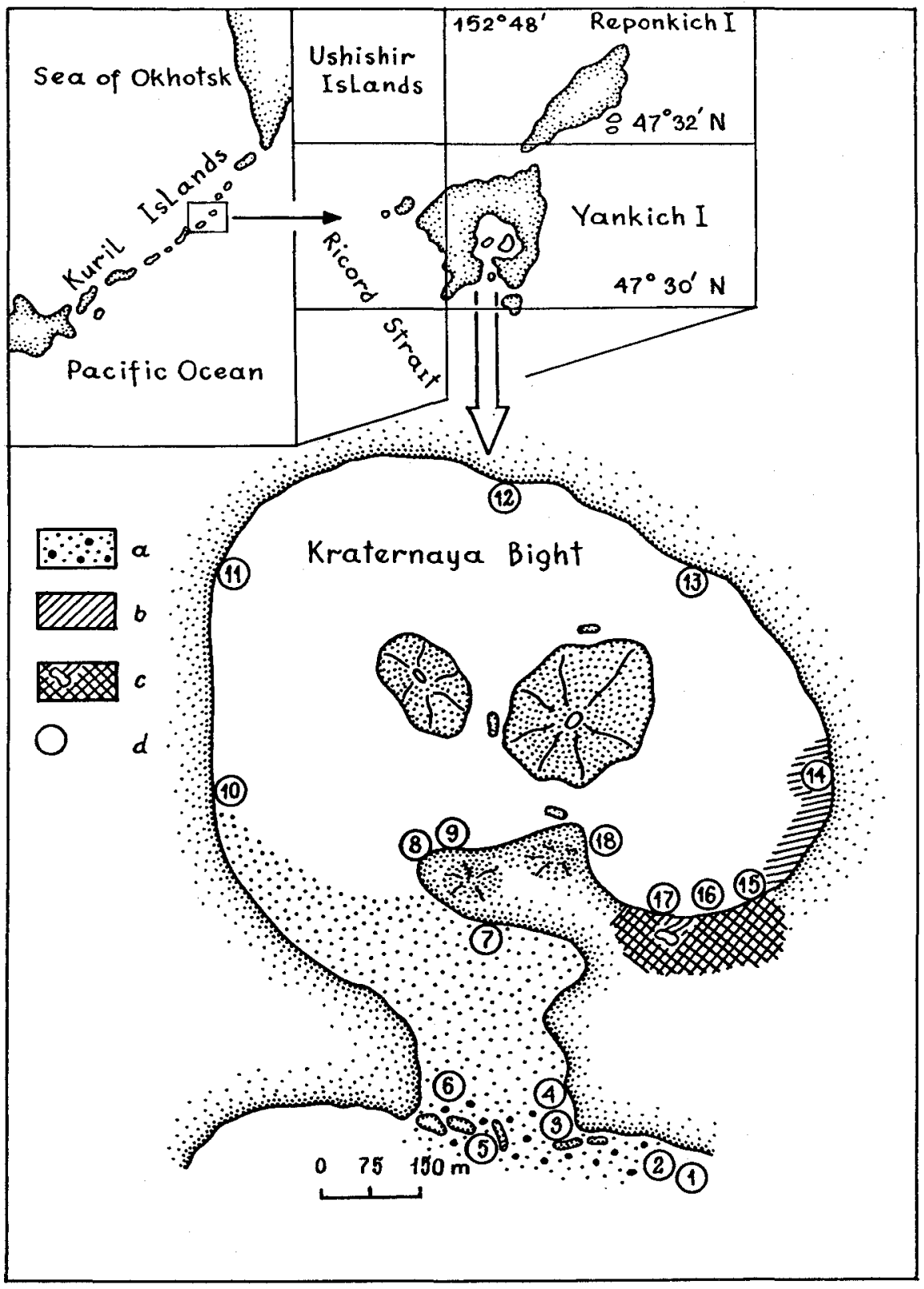

Fig. 1. Map of the investigated area and locations of sampling transects. a - sand bank and stones in the bight entrance; $b$ - area of volcanic water seeps; $c$ - terrestrial hydrosolfatar field, boiling volcanic water seeps; $d$-sampling transects. 
to gain broader information of the shore conditions and intertidal biota. Areas representing the major intertidal habitats were selected for more intensive study (Fig. 1, d), namely transect surveys across the intertidal zone. Altogether, 42 quantitative and 24 qualitative samples of macrobenthos were taken from 18 transects in the studied areas. The quantitative samples were collected using $0.01,0.25$ and $0.5 \mathrm{~m}^{2}$ square metal frames along each transect.

Table 1. Biomass (B, g wet wt $\left.\mathrm{m}^{-2}\right)$ and numbers $\left(\mathrm{N}, \mathrm{m}^{-2}\right)$ of intertidal macrobenthos on the open coast (Transects $1 \& 2$ )

\begin{tabular}{|c|c|c|c|c|c|c|c|}
\hline \multirow[t]{2}{*}{ Taxa } & \multirow{2}{*}{$\begin{array}{c}\text { Taxonomic } \\
\text { group* }\end{array}$} & \multicolumn{2}{|c|}{$\begin{array}{c}\mathrm{H} . \\
\text { High intertidal }\end{array}$} & \multicolumn{2}{|c|}{$\begin{array}{c}\text { M. } \\
\text { Middle intertidal }\end{array}$} & \multicolumn{2}{|c|}{$\begin{array}{c}\text { L. } \\
\text { Low intertidal }\end{array}$} \\
\hline & & $\mathrm{B}$ & $\mathrm{N}$ & $\mathrm{B}$ & $\mathrm{N}$ & $\mathrm{B}$ & $\mathrm{N}$ \\
\hline \multicolumn{8}{|l|}{$\overline{\text { PLANTS }}$} \\
\hline Urospora penicilliformis & $\mathrm{Ch}$ & 185.2 & - & - & - & - & - \\
\hline $\begin{array}{l}\text { Acrosiphonia duriuscula (with } \\
\text { epiphytic diatoms) }\end{array}$ & $\mathrm{Ch}$ & - & - & 350.0 & - & - & - \\
\hline Palmaria stenogona & $\mathrm{Rh}$ & - & - & 451.0 & - & - & - \\
\hline Iridaea cornucopiae & $\mathrm{Rh}$ & - & - & 1518.3 & - & - & - \\
\hline Monostroma grevillei & $\mathrm{Ch}$ & - & - & 20.8 & - & - & - \\
\hline Alaria sp. & $\mathrm{Ph}$ & $\longrightarrow$ & - & 6.5 & - & - & - \\
\hline Neoptilota asplenioides & $\mathrm{Rh}$ & - & - & 0.3 & - & - & - \\
\hline Laminaria longipes & $\mathrm{Ph}$ & - & - & - & - & $23,153.0$ & - \\
\hline Kallymeniaceae gen. sp. & $\mathrm{Rh}$ & - & - & - & - & 105.0 & - \\
\hline Ptilota filicina & $\mathrm{Rh}$ & - & - & - & - & 8.0 & - \\
\hline Total plants & & 185.2 & & 2346.9 & & $23,266.0$ & \\
\hline \multicolumn{8}{|l|}{ ANIMALS } \\
\hline Littorina sitkana & $\mathrm{Ga}$ & 2317.5 & 8400 & 10.25 & 420 & 34.0 & 600 \\
\hline Nucella freycinettii & $\mathrm{Ga}$ & - & - & 53.75 & 25 & - & - \\
\hline Parallorchestes ochotensis & $\mathrm{Am}$ & - & - & 13.2 & 2800 & 14.3 & 500 \\
\hline Nemertini & $\mathrm{Ne}$ & - & - & 1.5 & 375 & 11.0 & 2100 \\
\hline Turtonia minuta & $\mathrm{Bi}$ & - & - & 0.75 & 325 & 1.0 & 100 \\
\hline Idotea gurjanovae & Is & - & - & 6.5 & 750 & - & - \\
\hline Nereis pelagica & Po & - & - & 2.95 & 275 & 14.0 & 100 \\
\hline Pontogeneia makarovi & Am & - & - & 0.5 & 550 & - & - \\
\hline Boccardia sp. & Po & - & - & 2.1 & 50 & - & - \\
\hline Cucumaria vegae & Ho & - & - & 2.0 & 75 & 645.0 & 8600 \\
\hline Amphiglena pacifica & Po & - & - & 0.75 & 50 & - & - \\
\hline Allorchestes malleolus & Am & - & - & 0.15 & 50 & - & - \\
\hline Leptasterias alaskensis asiatica & Ast & - & - & - & - & 3.0 & 200 \\
\hline Sycon sp. & $\mathrm{Sp}$ & - & - & - & - & 37.0 & - \\
\hline Eteone longa & Po & - & - & - & - & 2.2 & 100 \\
\hline Typosyllis ehlersioides japonica & Po & - & - & - & - & 9.4 & 3700 \\
\hline Sabellidae gen. sp. & Po & - & - & - & - & 5.6 & 100 \\
\hline Actiniidae gen. sp. & $\mathrm{Ac}$ & - & - & - & - & 5.0 & 100 \\
\hline Cirratulus wladislavi & Po & - & - & - & - & 1.0 & 100 \\
\hline Abietinaria filicula filicula & Hy & - & - & - & - & 1.0 & - \\
\hline Lepidopecreum sp. & $\mathrm{Am}$ & - & - & - & - & 1.9 & 600 \\
\hline Ischyrocerus tzvetkovae & $\mathrm{Am}$ & - & - & - & - & 1.4 & 400 \\
\hline Phascolosoma sp. & $\mathrm{Si}$ & - & - & - & - & 1.0 & 100 \\
\hline Dysponetus pygmaeus & Po & - & - & - & - & 1.0 & 2400 \\
\hline Naineris quadricuspida & Po & - & - & - & - & 0.8 & 100 \\
\hline Turbellaria & $\mathrm{Tu}$ & - & - & - & - & 0.4 & 100 \\
\hline Phyllodocidae gen.sp. & Po & - & - & - & - & 0.4 & 100 \\
\hline Paraphoxus longirostris & $\mathrm{Am}$ & - & - & - & - & 0.8 & 700 \\
\hline Ampithoe djakonovi & $\mathrm{Am}$ & - & - & - & - & 0.4 & 100 \\
\hline Total animals & & 2317.5 & & 94.4 & & 792.0 & \\
\hline
\end{tabular}

*) Ch-Chlorophycota; Ph-Phaeophycota, Rh-Rhodophycota; Sp-Spongia; Hy-Hydrozoa; Ac-Actiniaria; Tu-Turbellaria; Ne-Nemertini; Si - Sipunculida; Po-Polychaeta; Ol-Oligochaeta; Ci - Cirripedia; Le - Leptostraca; Am - Amphipoda; Is - Isopoda; Ga-Gastropoda; Bi Bivalvia; Ast - Asteroidea; Ech - Echinoidea; Ho - Holothuroidea; As - Ascidia. 
The number of individuals and biomass of each species were calculated for $1 \mathrm{~m}^{2}$ area. The biomass of each species was determined as blotted wet weight. This procedure was necessary because the material was needed for subsequent taxonomic work.

\section{The Open Coast}

The substrate varies little along the open coast of Yankich Island. Abrupt rocky shores stretch all along the coast of this island. The rocky walls are mostly vertical and difficult for investigators to approach because of the surges, but at some places a narrow boulder beach is formed between the rocky headlands, consisting of relatively hard volcanic rocks. We studied one such boulder beach on the south-eastern coast of the island near the entrance to Kraternaya Bight (Transects 1 and 2). The wave action here was nearly constant and sometimes severe. Therefore, most of the intertidal zone proper, an area about $30-50 \mathrm{~m}$ wide, was occupied purely by lower intertidal laminarians with Laminaria longipes as the dominant species. The mean algal biomass was comparatively high (Table 1, L), but the number of species was very low, and the macroalgal flora included only two other species of red algae, Ptilota filicina and Kallymeniacea gen. sp. Animals were more diverse. The dominant species was the small sea cucumber Cucumaria vegae, which attained high densities along the sides of stones, beneath boulders, and among algae. Various polychaetes and amphipods were commonly found in holdfasts of laminarian growths.

The mid-intertidal fucoid community of Fucus evanescens is poorly developed in this area, mainly because of the strong surf, and it comprised the large algae Iridaea cornucopiae and Palmaria stenogona with an admixture of other small algae, especially a green alga Acrosiphonia duriuscula. The biomass of the algae in this community was about $1 / 10$, and the biomass of animals about $1 / 8.5$, of that in the lower intertidal community (Table $1, \mathrm{M}$ ). Common animals were the gastropods Nucella freycinettii and Littorina sitkana, an amphipod Parallorchestes ochotensis, and an isopod Idotea gurjanovae. The main breadth of the mid-intertidal belt in this area was about $5 \mathrm{~m}$.

The common upper-intertidal community of Littorina sitkana here was often replaced by patches of the small filamentous green alga Urospora penicilliformis, with a low biomass of about $200 \mathrm{~g} \mathrm{~m}^{-2}$ (Table $1, \mathrm{H}$ ).

\section{Entrance to Kraternaya Bight}

The entrance to Kraternaya Bight (Transects $3-7$ ) is somewhat sheltered from the open sea by stony reefs that are exposed at low water and are divided into two groups by a shallow and narrow, turbulent channel. These reefs are composed of boulders and rocks from 0.5 to $3 \mathrm{~m}$ in diameter. Besides these boulders, there are several high vertical rocks leaning against each other on the western reef. The shaded niches under these rocks are well protected from the surf. Between the stones are numerous tide pools of various sizes situated at different levels above the sea. Most of the tide-covered reefs are subject to the influence of strong tidal currents. Due to the considerable width of these reefs (several tens of metres), the wave action across the reefs is diminished. The water in this area appears to be unusually rich in nutrient salts and microelements, partly due to an inflow from Kraternaya Bight.

The heterogeneity of the substrate, with open and sheltered spaces, tide pools, and shaded niches, the turbidity of the water with good aeration but without shocking surf and very strong wave action, and, probably, the presence of small amounts of products of gaso-hydrothermal activity create extremely favourable conditions for rich intertidal biota. In fact, this environment supports a large number of plant and animal species, more than in all other parts of the island and even exceeding the number of species in many other regions 
of the high-boreal subzone. In particular, we found here such unusual forms for the boreal littoral zone as the polychaete Spinther sp., the echiurid Bonellia sp., and the brachiopod Diestothyris frontalis. Only in this area did we find Undariella, a recently described new genus of laminarian algae. The senior author has been studying the intertidal biota of the boreal region for more than 40 years, but he has never found as many as eight species of chitons living together at anywhere but here.

The richness and diversity of the intertidal life in this area are strongly pronounced only in the lower part of the intertidal zone (the infra-littoral fringe according to Stephenson \& Stephenson, 1972). Here, in the low intertidal zone, the laminarian belt, as is typical for the boreal zone, was well developed. In this area, Laminaria longipes, Alaria angusta, and $A$. marginata predominated. Other common algae were the laminarians Thalassiophyllum clathrus and Arthrothamnus kurilensis and small specimens of Laminaria bongardiana. The red algae Neoptilota asplenioides and Ptilota filicina formed an undergrowth. On Thalassiophyllum, encrustations of the red algae Hildenbrandtia prototypus and Titanoderma dispar occurred. Besides these algae, in the lower tide pools and niches, the moderate-sized brown alga Desmarestia aculeata, the red algae Constantinea rosa-marina, Iridaea cornucopiae, Palmaria stenogona, Odonthalia floccosa, Velatocarpus pustulosus, and the green algae Ulvaria splendens, Codium ritteri, and Acrosiphonia duriuscula were most common. A certain amount of the pink lithothamnion Clathromorphum loculosum and small patches of the brown encrusting alga Ralfsia fungiformis were also present in caves, tide pools, and shady places. Only in such shady niches with moderate wave exposure did we find a medium-sized laminarian alga that belongs to a new genus, Undariella (Petrov \& Kussakin, 1996). This alga has a thallus with an entire blade about $0.5 \mathrm{~m}$ long and fringed laterally with several rows of semicircular laminae.

Above the laminarian belt, these large brown seaweeds gradually disappeared and were replaced by red algae, predominantly Palmaria stenogona, Iridaea cornucopiae, Porphyra tasa, Halosaccion glandiforme, Ptilota filicina, Neoptilota asplenioides, and Velatocarpus pustulosus, with an admixture of a green alga Ulvaria splendens and a brown alga Fucus evanescens.

In the lower part of the mid-intertidal subzone, the most common algae were Iridaea cornucopiae and Fucus evanescens. In the upper part, Porphyra tasa with patches of Acrosiphonia saxatilis also occurred.

In the pools and under stones at the lowest tide level, a wealth of animal life was observed. Besides lithothamnion encrusting the bottoms of pools and the slopes, the stones were covered with various sponges and tunicates. Among the sponges, the amorphous, yellowish-green Halichondria panicea, pale grey Haliclona gracilis, and red Lissodendorix amaknakensis were usually abundant. Whitish calcareous sponges Sycon spp. occurred not only on the bottom, but on the holdfasts of various algae. Tunicate species were represented by a colonial Amaroucium sp. that formed amorphous masses, and Dendrodoa aggregata.

Among the stones, the gastropods Nucella freycinettii and Buccinum baeri, the green sea-urchin Strongylocentrotus droebachiensis, and the small six-rayed seastars Leptasterias alaskensis asiatica and $L$. camtschatica were common. The stones and holdfasts sheltered many shelled protozoans Gromia oviformis, brown turbellarians, brown and cream-coloured nemerteans, a sipunculid Phascolosoma japonicum, the polychaetes Nereis pelagica, Eteone longa, Cirratulus wladislawi, Amphiglena marita, and Harmothoe imbricata; an echiurid Bonellia sp., pycnogonids, a leptostracan Nebalia bipes, the amphipods Ischyrocerus tzvetkovae, Paracalliopiella pacifica, Pontogeneia makarovi, Caprella parapaulina, and many others; the isopods Gnorimosphaeroma noblei and Idotea aleutica; the chitons Spongioradsia aleutica, Schizoplax brandtii, Tonicella beringensis beringensis, and Placiphorella borealis; the gastropods Astyris kobai, Volutharpa ampullacea, and Onchidoris bilamellata; and the sea cucumber Eupentacta pseudoquinquesemita. Large holdfasts of brown algae, especially Thalassio- 
phyllum clathrus, were covered with small animals, such as various sponges, hydroids, bryozoans, chitons, the brachiopod Diestothyris frontalis, and the bivalve Turtonia minuta. On the laminarian blades various amphipods, the gastropods Margarites helicina (with egg masses) and Epheria porrecta (with egg capsules), and Lacuna minor occurred.

High-littoral life was developed only on the largest stones. In this subzone, three belts of Fucus evanescens, Porphyra tasa, and Urospora penicilliformis were usually discernible. In the lower part, besides the growths of Fucus evanescens we found patches of barnacles. Barnacles were the dominant inhabitants on the tops of big stones. It is characteristic that while one of the barnacles, Semibalanus cariosus, is common throughout the Kuril Islands, the second one, Balanus crenatus, does not occur intertidally anywhere else in this region. The animal community in the lowest part of the Fucus belt was about the same as in the laminarian belt; in the uppermost part Nucella, Littorina, Gnorimosphaeroma, Idotea, and amphipods occurred. The Porphyra belt was densely populated by Littorina sitkana, but this species was sparse on Urospora mats.

To collect valuable qualitative samples in an area with such a variety and abundance of life during these short visits was a laborious task. Therefore, our qualitative data for this area are especially fragmentary and not well-founded. The mean biomass value in the belts of Littorina sitkana was $666 \mathrm{~g} \mathrm{~m}^{-2}\left(\mathrm{~N}=6300 \mathrm{~m}^{-2}\right)$; for the Fucus evanescens belt it was 10.902 $\mathrm{gm}^{-2}$; for the Iridaea cornucopiae belt it was $1432 \mathrm{~g} \mathrm{~m}^{-2}$, and for the Balanus crenatus belt it was $9.200 \mathrm{~g} \mathrm{~m}^{-2}\left(\mathrm{~N}=15,100 \mathrm{~m}^{-2}\right)$.

Inside the west stone reef (Transect 6 ), where the wave action was weaker, the stones had a dense cover of Fucus evanescens. The most interesting feature was a rather frequent occurrence of Alaria spp. overlying thalli of Fucus evanescens. Therefore, the typical zonal patterns here was broken, and $F$. evanescens was often found over Alaria. We have not observed this phenomenon anywhere else.

North of these reefs, the inner part of the entrance presented a small basin protected from wave action, where boulders and stones alternated with sandy beaches inhabited by the polychaetes Abarenicola vagabunda oceanica, Nereis pelagica, Eteone longa, Capitella capitata, Naineris quadricuspida, and Microspio sp. and the amphipods Allorchestes carinata, Anonix affinis, Anisogammarus spasskii, Paraphoxus robusta, and $P$. longirostris.

In the lowest part of the sheltered stony intertidal zone, in the belt of Alaria marginata and $A$. angusta, another alariacean alga, Pleuropterum paradiseum, appeared. The midintertidal subzone was markedly divided, and Fucus evanescens formed a conspicuous belt. In addition to Fucus, among the usual constituents were Porphyra tasa, Semibalanus cariosus, and Nucella freycinettii. In many places, the sponges Halichondria panicea, a green alga Codium ritteri, and a brown alga Desmarestia aculeata occurred among stones. The most common red algae between the laminarian and fucoid belts were Iridaea cornucopiae, Palmaria stenogona, Halosaccion glandiforme, and Neorhodomela aculeata. An unusual feature for the West-Pacific boreal littoral zone was a dense growth of the barnacle Balanus crenatus on thalli of Fucus evanescens and on the shells of Nucella freycinettii. Sometimes B. crenatus formed such dense masses that the animals were forced to grow into a columnar shape. As a result, very high and thin, narrow-cylindrical shells were formed.

\section{Kraternaya Bight}

Kraternaya Bight is about 0.7 square kilometres in area, with a mean depth of about 25 $\mathrm{m}$ and a maximum depth of $63 \mathrm{~m}$. The bight is surrounded by abrupt rocky walls, with a strip of low coastal platform partly covered by high tide, between the walls and the sea. Thus, the intertidal zone is everywhere easily accessible for field investigations.

In contrast to the open sea around Yankich Island, the hydrographical and hydro- 
chemical regime of Kraternaya Bight (Transects 6-11) is characterised by a well-pronounced water stratification with respect to temperature, carbon dioxide content, $\mathrm{pH}$ value, and the concentration of oxygen, nutrients, and chlorophyll $a$. Three vertical water layers are noted in the bight: surface, intermediate (4-20 m), and deep-water (Tarasov et al., 1990). Of these layers, only the first actually interacts with the intertidal zone. According to these authors, the surface layer $(0-3 \mathrm{~m})$ has a slightly lowered salinity $(31-32 \%)$ and contains high concentrations of volcanogenic carbon dioxide and oxygen. Carbon dioxide is the main component of gas inflow from hydrothermal vents. Hydrogen sulphide and ammonia have been found only over the hydrothermal vents, particularly in the southeastern part of the bight (Zhirmunsky \& Tarasov, 1990). The oxygen content depended mostly on photosynthesis, which was most intense in August. In this month, oxygen oversaturation of up to $200 \%$ and a very high chlorophyll $a$ content were recorded, with pronounced daily variations in concentration (Tarasov et al., 1990). The temperature of the surface waters varies from 9 to $12.5^{\circ} \mathrm{C}$ in August and is particularly warm in the southeastern parts of the bight, where underwater vents with temperatures of $30^{\circ} \mathrm{C}$ and land solfatars are concentrated and produce more than $20,000 \mathrm{~m}^{3}$ of hydrothermal water per day (Zhirmunsky \& Tarasov, 1990). These hydrothermal vents issue solutions of manganese, iron, zinc, copper, nickel, and cadmium with 2 to 3 orders of magnitude higher concentrations than in the open sea around the island (Shulkin, 1989).

The average content of dissolved organic matter in the bight is 5 to 8 times higher than in the open sea (5 to $8 \mathrm{mg}^{-1}$ and $1 \mathrm{mg} \mathrm{l}^{-1}$, respectively) (Khristoforova, 1989). The biomass of plankton is high (up to $1 \mathrm{~g} \mathrm{~m}^{-3}$ ) from the surface down to $40 \mathrm{~m}$ (Zhirmunsky \& Tarasov, 1990). These authors also stated that a rich and diverse subtidal macrobenthos flourished on the bottom of this bight. The highest plant biomass (up to $30 \mathrm{~kg}$ wet wt $\mathrm{m}^{-2}$ ) is contributed by Alaria at a depth of $5-8 \mathrm{~m}$ in the vicinity of cold effluents free of hydrogen sulphide but high in $\mathrm{N}-\mathrm{NH}_{4}, \mathrm{P}-\mathrm{PO}_{4}$, iron, and manganese. The highest biomass of bottom invertebrates (up to $10 \mathrm{~kg} \mathrm{~m}^{-2}$ ) was observed in a muddy community dominated by Cerianthus lloydii, sedentary polychaetes and burrowing bivalves (Tarasov et al., 1990).

On the whole, Kraternaya Bight is a semi-closed, eutrophic, small sea basin with obviously recent volcanic activity. This activity and numerous gaso-hydrothermal vents influence the species diversity and the composition and structure of all marine communities in the bight. The influence of volcanic activity in this bight is accompanied by a reduction in species number and a significant increase in the population density and biomass of one or several species adapted to unusual hydrochemical regimes (Tarasov et al., 1988). When considering particularly energetic dynamics of environmental conditions in the intertidal zone, it is very interesting to trace the influence of gaso-hydrothermal activity on the littoral biota in different areas of this bight.

Kraternaya Bight is well protected from wind from practically all directions and is separated from the open sea; therefore, it is well sheltered from surf and wave action. On the other hand, strong tidal currents assist the inflow of clean water from the open sea and remove the products of gaso-hydrothermal activity from the inland waters of the bight. The rise and fall of the tides are not affected by surf, so the zonation between the tide-marks coincides generally with the basic tidal levels.

The sheltered shore of Kraternaya Bight consists of a gently sloping pebbly-boulder beach underlain by sand. In some places, it is interrupted by sandy beaches with detached boulders. These beaches are more common in the lower intertidal zone. Only in the southeastern, innermost part of the bight, which is partly closed by two islets, is the intertidal biota subject to the influence of complex variations of temperature and hydrochemical characteristics caused by gaso-hydrothermal vents. However, tidal stirring decreases any harmful influence of volcanic activity in this area. 
Along most of the coastline, the lowest part of the intertidal zone, essentially the laminarian belt, was dominated by Alaria marginata, $A$. angusta, and Pleuropterum paradiseum. The biomass of these three species $\left(26,472 \mathrm{~g} \mathrm{~m}^{-2}\right)$ was responsible for more than $90 \%$ of the total plant biomass (Table 2, AP). Associated with these algae were the subsidiary species Ulvaria splendens, Velatocarpus pustulosus, and Fucus evanescens. The barnacles Balanus crenatus and Semibalanus cariosus, the gastropods Nucella freycinettii and Littorina sitkana, and the bivalve Turtonia minuta were the most common animals. Among the conspicuous elements of the fauna were the sponge Halichondria panicea, a sea anemone Bunodactis sp., the polychaetes Harmothoe imbricata, Nereis pelagica, Eteone longa, and Naineris quadricuspida, an isopod Idotea gurjanovae, the amphipods Anisogammarus locustoides and Ischyrocerus chamissoi, the gastropods Nucella freycinettii, Cartilagovelutina beringensis, and Onchidoris bilamellata, the echinoderms Leptasterias spp., Cucumaria vegae, and Eupentacta pseudoquinquesemita, and an ascidian Ascidia collosa.

The sea-urchin Strongylocentrotus droebachiensis and the polychaetes Polydora vulcanica and Abarenicola vagabunda were the most conspicuous among the animals on sandy bottoms in the lowest intertidal.

Above the laminarian belt, two communities were discernible (Table 2, BN and BU). The most typical usually was a belt dominated by Balanus crenatus and Nucella freycinettii, with a scanty growth of small algae. Balanus crenatus was crowded not only on the tops of stones but also on the blades of Fucus. The most common animals besides Balanus and Nucella were a nemertean Nepemplectonema sp., the polychaetes Nereis pelagica and Eteone longa, a gastropod Littorina sitkana, a bivalve Turtonia minuta, a seastar Leptasterias alaskensis asiatica, and an ascidian Ascidia callosa.

The community of Balanus crenatus and Ulvaria splendens was found only in some places. Besides Ulvaria, there were small brown algae, Melanosiphon intestinalis and Pilayella litoralis, and the green alga Acrosiphonia duriuscula. The animals and their biomass were about the same as in the Balanus community (Table 2, BU). Also there were populations of the polychaete Polydora vulcanica with a biomass of up to $10 \mathrm{~kg} \mathrm{~m}^{-2}$.

Most of the mid-littoral zone was covered with a dense growth of Fucus evanescens, with an admixture of the red algae Iridaea cornucopiae and Palmaria stenogona of the lowest levels. The plant biomass was very high, which was typical of the Fucus community in sheltered areas of the boreal zone (Table 3, A). Among the most common animals, there were masses of the gelatinous colonial ascidian Amaroucium sp., the polychaete Nereis vexillosa, the barnacle Balanus crenatus, and the gastropods Littorina sitkana and Nucella freycinettii. The total amount of animals achieved a biomass of up to $4 \mathrm{~kg}$ wet wt $\mathrm{m}^{-2}$ (Table $3, \mathrm{~F}$ ).

In the mid-littoral subzone, we did not observe any true balanoid belt, but encountered populations of Semibalanus cariosus as patches of up to 1-2 $\mathrm{m}^{2}$ between fucoid growth. In these patches the algae were rare $\left(65.5 \mathrm{~g} \mathrm{~m}^{-2}\right)$, but the total animal biomass was more than one hundred times higher (Table $3, \mathrm{~S}$ ). In a few places, brilliant green patches of small Acrosiphonia duriuscula and Blidingia minuta (Table 3, AB) or brown tufts of Analipus japonicus were found (Table 3, A). The fauna include numerous Balanus crenatus, Nucella freycinettii, Littorina sitkana, Onchidoris bilamellata, Turtonia minuta, Idotea gurjanovae, and nemerteans. Total plant and animal biomass in the Analipus tufts were both very high and nearly equal in value (Table $3, \mathrm{~A}$ ). The patches of green algae were populated by rare Littorina sitkana and sparse Balanus crenatus, Gnorimosphaeroma noblei, and Modiolus phenax. The total biomass of plants and animals was small (Table 3, S).

The upper intertidal subzone (the supra-littoral fringe) had a population of the small gastropod Littorina sitkana with an average biomass of $1376 \mathrm{~g} \mathrm{~m}^{-2}$. There were also irregular patches of the green alga Urospora penicilliformis. The sandy areas were populated by the beach hoppers Talorchestia ochotensis. 
Comparatively cool gaso-hydrothermal vents with a temperature of $10-34^{\circ} \mathrm{C}$ occurred all along the northern shore of the bight. These waters contained no hydrogen sulphide, but $\mathrm{CO}_{2}$ and high concentrations of dissolved manganese, iron, zinc, and other metals were present. Vent gases contained $\mathrm{CO}_{2}, \mathrm{~N}_{2}, \mathrm{He}, \mathrm{CH}_{4}$, and $\mathrm{H}_{2}$ (Tarasov et al., 1990).

In this area (Transect 7) with a temperature of $10^{\circ} \mathrm{C}$, algae and some animals were

Table 2. Biomass $\left(\mathrm{B}\right.$, wet wt $\left.\mathrm{m}^{-2}\right)$ and numbers $\left(\mathrm{N}, \mathrm{m}^{-2}\right)$ of intertidal macrobenthos in the low intertidal zone in the bight (Transects 8-13)

\begin{tabular}{|c|c|c|c|c|c|c|c|}
\hline Taxa & \multirow[t]{2}{*}{$\begin{array}{l}\text { Taxonomic } \\
\text { group* }\end{array}$} & \multicolumn{2}{|c|}{$\underset{\mathrm{B}}{\text { Alaria }} \underset{\mathrm{N}}{\mathrm{AP}}$} & \multicolumn{2}{|c|}{$\begin{array}{c}\text { BN. } \\
\text { Balanus }+ \\
\text { Nucella belt }\end{array}$} & \multicolumn{2}{|c|}{$\begin{array}{c}\text { BU. } \\
\text { Balanus+ } \\
\text { Ulvaria } \\
\text { patches }\end{array}$} \\
\hline \multicolumn{7}{|l|}{ PLANTS } & \\
\hline $\begin{array}{l}\text { Alaria marginata (with epiphytic } \\
\text { Rhodymenia pertusa) }\end{array}$ & $\mathrm{Ph}$ & $10,576.0$ & - & - & - & - & - \\
\hline Pleuropterum paradiseum & $\mathrm{Ph}$ & 9303.0 & - & - & - & - & - \\
\hline $\begin{array}{l}\text { Aralia angusta (with epiphytic } \\
\text { Ectocarpus sp.) }\end{array}$ & $\mathrm{Ph}$ & 6593.0 & - & - & - & - & - \\
\hline Ulvaria splendens & $\mathrm{Ch}$ & - & - & - & - & 780.8 & - \\
\hline $\begin{array}{l}\text { Melanosiphon intestinalis f. complanatus } \\
\text { (with epiphytic Pilayella litoralis) }\end{array}$ & $\mathrm{Ph}$ & - & - & - & - & 388.0 & - \\
\hline Analipus japonicus & $\mathrm{Ph}$ & 258.0 & - & - & - & - & - \\
\hline Acrosiphonia duriuscula & $\mathrm{Ch}$ & 229.0 & - & 0.3 & - & 522.0 & - \\
\hline Fucus evanescens & $\mathrm{Ph}$ & - & - & 186.3 & - & - & - \\
\hline Palmaria stenogona & $\mathrm{Rh}$ & 80.5 & - & - & - & - & $\rightarrow$ \\
\hline Pilayella litoralis & $\mathrm{Ph}$ & 9.5 & - & - & - & - & $\rightarrow$ \\
\hline $\begin{array}{l}\text { Rhodophycota indet. } \\
\text { Total plants }\end{array}$ & $\mathrm{Rh}$ & $\begin{array}{c}- \\
27,049.7\end{array}$ & - & $\begin{array}{r}1.5 \\
188.1\end{array}$ & - & $\begin{array}{c}- \\
1690.8\end{array}$ & - \\
\hline \multicolumn{8}{|l|}{ ANIMALS } \\
\hline Balanus crenatus & $\mathrm{Ci}$ & 1793.5 & 27,517 & 2505.7 & 17,300 & 3690.0 & 19,925 \\
\hline Nucella freycinetii & $\mathrm{Ga}$ & 269.0 & 167 & 1164.6 & 450 & 588.75 & 150 \\
\hline Polydora vulcanica & Po & 231.8 & 22,133 & - & - & - & - \\
\hline Semibalanus cariosus & $\mathrm{Ci}$ & 621.2 & 33 & 0.5 & 17 & - & - \\
\hline Turtonia minuta & $\mathrm{Bi}$ & 132.5 & 18,167 & 19.5 & 2153 & 8.25 & 700 \\
\hline Littorina sitkana & $\mathrm{Ga}$ & 127.5 & 4533 & 80.0 & 2150 & 28.75 & 475 \\
\hline Nemertini & $\mathrm{Ne}$ & 80.5 & 14,450 & 93.8 & 29,183 & 172.3 & 36,600 \\
\hline Nereis pelagica & Po & 29.7 & 1067 & 111.3 & 3150 & 1.85 & 150 \\
\hline Leptasterias alaskensis asiatica & Ast & - & - & 38.5 & 17 & - & - \\
\hline $\begin{array}{l}\text { Anisogammarus (Eogammarus) } \\
\text { locustoides }\end{array}$ & Am & 10.1 & 550 & - & - & - & - \\
\hline Cucumaria vegae & Ho & 8.9 & 33 & - & - & - & - \\
\hline Eteone longa & Po & 5.8 & 650 & 28.5 & 6833 & 0.1 & 25 \\
\hline Gnorimosphaeroma noblei & Is & 1.3 & 283 & 0.3 & 33 & 1.5 & 50 \\
\hline Idotea gurjanovae & Is & 0.8 & 17 & - & - & - & - \\
\hline Onchidoris bilamellata & $\mathrm{Ga}$ & 0.8 & 17 & - & - & - & - \\
\hline Ischyrocerus chamissoi & $\mathrm{Am}$ & 0.6 & 500 & - & - & 4.2 & 2750 \\
\hline Bunodactis sp. & Ac & - & - & 2.5 & 33 & - & - \\
\hline Eupentacta pseudoquinquesemita & Ho & - & - & 4.3 & 17 & - & - \\
\hline Cirratulus wladislavi & Po & - & - & 3.6 & 50 & - & - \\
\hline Orbiniella nuda & Po & 0.1 & 33 & 0.6 & 100 & 12.2 & 8025 \\
\hline Ischyrocerus dezhnevi & $\mathrm{Am}$ & - & - & - & - & 1.25 & 1050 \\
\hline Naineris quadricuspida & Po & - & - & 0.5 & 50 & - & - \\
\hline Pontogenea makarovi & $\mathrm{Am}$ & 0.02 & 17 & - & - & 0.7 & 175 \\
\hline Modiolus phenax & $\mathrm{Bi}$ & - & - & 0.3 & 33 & - & - \\
\hline Ampithoe djakonovi & $\mathrm{Am}$ & - & - & - & - & 0.4 & 100 \\
\hline Ischyroceras anguipes & $\mathrm{Am}$ & - & - & - & - & 0.2 & 75 \\
\hline Harmothoe imbricata & Po & 0.2 & 33 & - & - & 0.3 & 50 \\
\hline Falsicingula sp. & $\mathrm{Ga}$ & 0.2 & 17 & - & - & - & - \\
\hline Corophium steinegeri & $\mathrm{Am}$ & 0.1 & 100 & 0.25 & 117 & 0.05 & 50 \\
\hline Total animals & & 3324.6 & & 4054.8 & & 4510.8 & \\
\hline
\end{tabular}

*) See Table 1. 
covered with rusty deposit of ferric oxide. In others respects, the intertidal biota in this area was about the same as elsewhere in such sheltered localities along the coast of the bight. The laminarian belt extended from well above the mean low water of spring tide to the infralittoral zone. Only one species, Alaria angusta, was dominant (biomass up to $25 \mathrm{~kg} \mathrm{~m}^{-2}$ ). Among the growths of this plant was an undergrowth of the small algae Ulvaria splendens, Acrosiphonia duriuscula, and Melanosiphon sp., and various animals, usually Balanus crenatus, Nucella freycinettii, the amphipods Ischyrocerus anguipes, I. deshnevi, and I. chamissoi, nemerteans, and the polychaetes Nereis pelagica, Harmothoe imbricata and Orbiniella nuga.

The biomass of Fucus evanescens in the middle intertidal subzone was $23 \mathrm{~kg} \mathrm{~m}^{-2}$. The most conspicuous animals here were about the same as in the laminarian belt.

The upper intertidal subzone had a definite Littorina belt with a biomass of $482 \mathrm{~g} \mathrm{~m}^{-2}$.

Finally, the intertidal biota of the southeastern part of the bight (Transects 14-17), which is under the influence of hot gaso-hydrothermal vents, was examined. In that area, a great

Table 3. Biomass $\left(B, g\right.$ wet $\left.w t \mathrm{~m}^{-2}\right)$ and numbers $\left(\mathrm{N}, \mathrm{m}^{-2}\right)$ of intertidal macrobenthos in the middle intertidal zone in the bight (Transects $8-13$ )

\begin{tabular}{|c|c|c|c|c|c|c|c|c|c|}
\hline Taxa & \multirow[t]{2}{*}{$\begin{array}{c}\text { Taxonomic } \\
\text { group* }\end{array}$} & \multicolumn{2}{|c|}{$\begin{array}{l}\text { F. } \\
\text { Fucus belt }\end{array}$} & \multicolumn{2}{|c|}{ A. } & \multicolumn{2}{|c|}{$\begin{array}{c}\mathrm{AB} . \\
\text { Acrosiphonia }+ \\
\text { Blidingia patches }\end{array}$} & \multicolumn{2}{|c|}{$\begin{array}{c}\mathrm{S} \\
\text { Semibalanus } \\
\text { settlings }\end{array}$} \\
\hline \multicolumn{9}{|l|}{ PLANTS } & \\
\hline Fucus evanescens & $\mathrm{Ph}$ & $25,111.6$ & - & - & - & 4.5 & - & 4.0 & - \\
\hline Analipus japonicus & $\mathrm{Ph}$ & - & - & 3692.0 & - & - & - & - & - \\
\hline $\begin{array}{l}\text { Acrosiphonia duriuscula }+ \\
\text { diatoms }\end{array}$ & $\mathrm{Ch}$ & - & - & - & - & 372.75 & - & 61.0 & - \\
\hline Blidigia minima & $\mathrm{Ch}$ & - & - & - & - & 233.75 & - & - & - \\
\hline Iridaea cornucopiae & $\mathrm{Rh}$ & 1109.4 & - & - & - & 1.3 & - & 0.5 & - \\
\hline Palmaria stenogona & $\mathrm{Rh}$ & 735.8 & - & - & - & 167.0 & - & - & - \\
\hline Total plants & & $26,956.8$ & & 3692.0 & & 779.3 & & 65.5 & \\
\hline \multicolumn{10}{|l|}{ ANIMALS } \\
\hline Semibalanus cariosus & $\mathrm{Ci}$ & - & - & 38.3 & 100 & - & - & 6052.5 & 200 \\
\hline Amaroucium sp. & As & 2002.0 & - & - & - & - & - & - & - \\
\hline Balanus crenatus & $\mathrm{Ci}$ & 279.1 & 28,100 & 1388.0 & 26300 & 30.5 & 1750 & 30.0 & 2200 \\
\hline Nucella freycinettii & $\mathrm{Ga}$ & 283.1 & 125 & 1088.0 & 200 & - & - & 3.0 & 50 \\
\hline Nereis vexillosa & Po & 705.0 & 2700 & - & - & - & - & - & - \\
\hline Littorina sitkana & $\mathrm{Ga}$ & 343.9 & 7235 & 323.0 & 72 & 208.5 & 860 & 60.5 & 2400 \\
\hline Nemertini & $\mathrm{Ne}$ & 28.1 & 5520 & 256.0 & 17,200 & - & - & 132.5 & 17,250 \\
\hline Strongylocentrotus droebachiensis & Ech & - & - & - & - & - & - & 196.0 & 25 \\
\hline Turtonia minuta & $\mathrm{Bi}$ & 11.4 & 1663 & 133.01 & 12,100 & - & - & 73.0 & 17,150 \\
\hline Modiolus phenax & $\mathrm{Bi}$ & 89.0 & 9350 & - & - & 0.5 & 50 & 38.0 & 8950 \\
\hline Cucumaria vegae & Ho & 83.5 & 300 & - & - & - & - & - & - \\
\hline Onchidoris bilamellata & $\mathrm{Ga}$ & 5.6 & 200 & 62.0 & 1000 & - & - & - & - \\
\hline Idotea gurjanovae & Is & - & - & 42.2 & 100 & - & - & - & - \\
\hline Allorchestes carinata & $\mathrm{Am}$ & 41.1 & 100 & - & - & - & - & - & - \\
\hline Harmothoe imbricata & Po & 32.5 & 900 & 0.8 & 100 & - & - & - & - \\
\hline Flabelligera affinis & Po & 4.7 & 100 & - & - & - & - & - & - \\
\hline Ampithoe volki & Am & 5.9 & 300 & - & - & - & - & - & - \\
\hline Bunodactis sp. & Ac & 3.75 & 25 & - & - & - & - & - & - \\
\hline Gnorimosphaeroma noblei & Is & 1.25 & 725 & - & - & 0.75 & 100 & 4.0 & 1750 \\
\hline Naineris quadricuspida & Po & 1.6 & 200 & - & - & - & - & - & - \\
\hline Nereis pelagica & Po & 0.6 & 35 & 9.6 & 1600 & - & - & - & - \\
\hline $\begin{array}{l}\text { Anisogammarus (Eogammarus) } \\
\text { locustoides }\end{array}$ & $\mathrm{Am}$ & - & - & - & - & - & - & 0.6 & 250 \\
\hline Orbiniella nuda & Po & 0.6 & 100 & - & - & - & - & - & - \\
\hline Turbellaria & $\mathrm{Tu}$ & 0.5 & 50 & - & - & - & - & - & - \\
\hline Pontogeneia makarovi & Am & 0.3 & 30 & 1.4 & 500 & - & - & - & - \\
\hline Eteone longa & Po & 3.4 & 155 & 0.2 & 100 & - & - & - & - \\
\hline Total animals & & 3926.9 & & 3342.5 & & 240.25 & & 6590.1 & \\
\hline
\end{tabular}

*) See Table 1 . 
land hydrosolfatar field that consists of thick sulphur deposits with fumaroles is located (Fig. C). The solfatar effluents with a water temperature $92-96^{\circ} \mathrm{C}$ and also a warm spring enter the bight. The temperature of the surface waters in this area was high in August at $20-22^{\circ}$ $\mathrm{C}$, compared to $10-13^{\circ} \mathrm{C}$ elsewhere in the bight and only $2.5-3.5^{\circ} \mathrm{C}$ around the island. These hydrothermal waters with $\mathrm{pH}$ of 3.5 to 4 contained hydrogen sulphide, other sulphur compounds, silicon, phosphorus, and high concentration of manganese, iron, zinc, copper, nickel, and cadmium: 2 to 3 orders of magnitude more than in the waters surrounding the bight (Shulkin, 1989; Zhirmunsky \& Tarasov, 1990).

The number of intertidal species here was much lower than in other parts of the bight, but plant and especially animal biomasses were high. Some species that are well adapted to the extreme conditions of life in the vicinity of gaso-hydrothermal vents were plentiful only in this area. The most common species of animal was the white barnacle Balanus crenatus.

The hot spring intertidal biota along a transect 100 metres west of the area of volcanic activity differed from that found under usual condition in the bight. The surface of the sand, pebbles, and boulders here was covered with a reddish-brown film. In the lower part of the intertidal zone, the laminarian belt still remains, although this belt often alternated with irregular patches of the burrowing polychaete Polydora vulcanica with a biomass of up to 18 $\mathrm{kg} \mathrm{m} \mathrm{m}^{-2}$ or populations of Balanus crenatus (average biomass about $4.9 \mathrm{~kg} \mathrm{~m}^{-2}$ ) (Table 4 , Po and $\mathrm{Ba}$ ).

In the laminarian belt, Pleuropterum paradiseum and Alaria marginata were dominant, but neither alga was abundant, with an average biomass of less than $1.5 \mathrm{~kg} \mathrm{~m}^{-2}$. The blades of Pleuropterum were often covered with the brown epiphytic alga Pilayella litoralis. Animal life was scanty in the laminarian belt (Table 4, Pl), but much more abundant in the Balanus and Polydora patches (Table 4, Po and Ba). Boulders were covered with dense masses of Balanus crenatus. In places, barnacles were replaced by the brown algae, Fucus evanescens and Punctaria plantaguinea, or the red alga Mastocarpus pacificus. Conspicuous animals in the Balanus belt were Halichondria panicea, Nereis pelagica, Phyllodoce groenlandica, Littorina sitkana, Nucella freycinettii, Onchidoris bilamellata, Nebalia bipes, Bunodactis sp., Idotea aleutica, and Eupentacta pseudoquinquesemita. The animal biomass was about $5 \mathrm{~kg} \mathrm{~m}^{-2}$, while the plant biomass was only $120 \mathrm{~g} \mathrm{~m}^{-2}$ (Table 4, Ba).

The populations of Polydora vulcanica were uniform; algae were absent and other animals, such as Nereis pelagica, Eteone longa, Phyllodoce sp., and Littorina sitkana, were rare. The mean biomass $\left(8.7 \mathrm{~kg} \mathrm{~m}^{-2}\right)$ was predominantly composed of the single dominant species.

Most of mid-littoral subzone supported growths of Fucus evanescens and Mastocarpus pacificus. Because these algae occurred only on the boulders scattered on the sandy beach, the plant biomass was relatively small (Table 4, Fu). Animals in this belt were the same as in the lower intertidal zone, but the amphipods Anisogammarus locustoides and Corophium steinegeri were more numerous.

The upper part of the mid-littoral and the upper intertidal subzone were populated only by Littorina sitkana with an average biomass of almost $3 \mathrm{~kg} \mathrm{~m}^{-2}$.

Around the inflow of gaso-hydrothermal water into the bight, the water temperature was $38^{\circ} \mathrm{C}$ and macrobenthos was absent. Near this place, sterile Fucus evanescens appeared. The sea floor and fucoid thalli were covered with a yellowish-white film of sulphur compounds.

A short distance away of the warm inflow (Transect 16), Balanus crenatus appeared settled on boulders, shells of Nucella, and especially on thalli of Fucus. Fucoid blades free from Balanus growth were covered with a small green alga, Acrosiphonia duriuscula. On the tops of low-level boulders and among the algae, Littorina sitkana and Nucella freycinettii were common, and beneath them were found abundantly the polychaetes, Harmothoe imbricata, Nereis pelagica, and Eteone longa, the amphipod Corophium steinegeri, the gastropod On. chidoris bilamellata, the bivalve Hiatella arctica and the fishes Myoxocephalus brandtii, $M$. 
Table 4. Biomass $\left(\mathrm{B}, \mathrm{g}\right.$ wet $\left.\mathrm{wt} \mathrm{m}^{-2}\right)$ and numbers $\left(\mathrm{N}, \mathrm{m}^{-2}\right)$ of the intertidal macrobenthos near the hydrosolfatar field (Transects 16-17)

\begin{tabular}{|c|c|c|c|c|c|c|c|c|c|}
\hline Taxa & $\begin{array}{l}\text { Taxonomic } \\
\text { group* }\end{array}$ & \multicolumn{2}{|c|}{\begin{tabular}{l}
\multicolumn{2}{c}{ Po. } \\
$\begin{array}{c}\text { Polydora population } \\
\text { B } \quad \mathrm{N}\end{array}$
\end{tabular}} & \multicolumn{2}{|c|}{$\begin{array}{c}\text { Ba. } \\
\text { Balanus belt } \\
\mathrm{B}\end{array}$} & \multicolumn{2}{|c|}{$\begin{array}{c}\text { Pl. } \\
\text { Pleuropterum } \\
\mathrm{B} \quad \mathrm{N}\end{array}$} & \multicolumn{2}{|c|}{$\begin{array}{c}\text { Fu. } \\
\text { Fucus belt }\end{array}$} \\
\hline \multicolumn{10}{|l|}{ PLANTS } \\
\hline $\begin{array}{l}\text { Pleuropterum paradiseum (with } \\
\text { epiphytic Pilayella litoralis) }\end{array}$ & $\mathrm{Ph}$ & - & - & 120.0 & - & 905.0 & - & - & - \\
\hline Fucus evanescens & $\mathrm{Ph}$ & - & - & - & - & - & - & 1276.8 & - \\
\hline Mastocarpus pacificus & $\mathrm{Rh}$ & - & - & - & - & - & - & 580.0 & - \\
\hline Alaria marginata & $\mathrm{Ph}$ & - & - & - & - & 531.7 & - & - & - \\
\hline Total plants & & & & 120.0 & & 1436.7 & & 1856.8 & \\
\hline \multicolumn{10}{|l|}{ ANIMALS } \\
\hline Polydora vulcanica & Po & 8624.9 & 105,300 & - & - & - & - & - & - \\
\hline Balanus crenatus & $\mathrm{Ci}$ & - & - & 4500.0 & 4046 & 222.0 & 4000 & 424.0 & 3733 \\
\hline Littorina sitkana & $\mathrm{Ga}$ & 25.0 & 100 & 8.3 & 163 & - & - & 55.0 & 893 \\
\hline $\begin{array}{l}\text { Anisogammarus (Eogammarus) } \\
\quad \text { locustoides }\end{array}$ & $\mathrm{Am}$ & - & - & 17.9 & 950 & - & - & 270.7 & 7885 \\
\hline Nereis pelagica & Po & 19.0 & I000 & 125.9 & 627 & 38.2 & 400 & 3.8 & 40 \\
\hline Turtonia minuta & $\mathrm{Bi}$ & - & - & 111.3 & 4505 & 2.0 & 400 & 34.0 & 4370 \\
\hline Nucella freycinettii & $\mathrm{Ga}$ & - & - & 66.0 & 40 & - & - & 10.0 & 50 \\
\hline Corophium steinegeri & $\mathrm{Am}$ & - & - & 0.3 & 310 & 5.1 & 4950 & 25.1 & 6925 \\
\hline $\begin{array}{l}\text { Phyllodoce (Anaitides) } \\
\text { groenlandica }\end{array}$ & Po & - & - & 25.9 & 30 & - & - & - & - \\
\hline Nemertini & $\mathrm{Ne}$ & - & - & 10.0 & 10,800 & 2.0 & 300 & 1.4 & 530 \\
\hline Turbellaria & $\mathrm{Tu}$ & - & - & 1.6 & 200 & - & - & 9.0 & 200 \\
\hline Eteone longa & Po & 5.1 & 500 & 3.8 & 110 & - & - & 0.6 & 30 \\
\hline Phyllodoce sp. & Po & 4.0 & 100 & - & - & - & - & - & - \\
\hline Nebalia bipes & Le & - & - & 2.0 & 80 & - & - & $\rightarrow$ & - \\
\hline Spionidae gen. sp. & Po & 1.3 & 67 & - & - & - & - & - & - \\
\hline Terebellidae gen. sp. & Po & - & - & 1.5 & 10 & - & - & - & - \\
\hline Ampithoe sp. & $\mathrm{Am}$ & 3.7 & 100 & - & - & 0.9 & 30 & - & - \\
\hline Naineris quadricuspida & Po & 1.0 & 200 & - & - & - & - & - & - \\
\hline $\begin{array}{l}\text { Anisogammarus (Spinulo- } \\
\text { gammarus) ochotensis }\end{array}$ & Am & - & - & - & - & 0.7 & 20 & - & - \\
\hline Naineris jacutica & Po & - & - & 0.7 & 50 & - & - & - & - \\
\hline Bunodactis sp. & $\mathrm{Ac}$ & - & - & 0.5 & 20 & - & - & - & - \\
\hline Orbiniella nuda & Po & - & - & 0.4 & 67 & - & - & - & - \\
\hline Oligochaeta & OI & - & - & - & - & - & - & - & - \\
\hline Capitella capitata & Po & - & - & 0.02 & 10 & - & - & - & - \\
\hline Ampithoe djakonovi & $\mathrm{Am}$ & - & - & - & - & 0.03 & 100 & - & - \\
\hline Total of animals & & 8684.0 & & 4876.1 & & 270.9 & & 833.8 & \\
\hline
\end{tabular}

*) See Table 1.

stelleri, M. polyacanthocephalus, Ascoldia variegata, and Krusensterniella sp. These fishes, although abundant, were very small (22-64 $\mathrm{mm}$ in length). The mean biomass was $235 \mathrm{~g} \mathrm{~m}^{-2}$ for polychaetes, $17 \mathrm{~g} \mathrm{~m}^{-2}$ for amphipods, and $5 \mathrm{~g} \mathrm{~m}^{-2}$ for littorinids, while the biomass of Balanus crenatus was much greater and reached $4850 \mathrm{~g} \mathrm{~m}^{-2}$.

There were no laminarians in the lower intertidal and no littorinids in the upper intertidal subzones.

\section{Discussion and Conclusions}

A comparison of the characteristic species composition and zonal patterns between Yankich Island and other Kuril Islands reveals four essential types of features.

1. Features common to all Kuril Islands.

The basic zonation pattern common to all of them includes: the presence of laminarian, Fucus evanescens, Semibalanus cariosus, and Littorina sitkana belts; the development of undergrowths of various red algae, Palmaria stenogona, Halosaccion glandiforme, Neoptilota 
asplenioides, Ptilota filicina, and others, in the laminarian belt and between the laminarian and fucoid belts. A considerable affinity between the high-boreal middle and northern Kurils and the low-boreal islands is demonstrated by the presence of many plant and animal species in common. These species are usually distributed widely throughout the boreal zone, such as Mytilus edulis, Hiatella arctica, Halichondria panicea, Eulalia viridis, Eteone longa, Harmothoe imbricata, Nereis pelagica, Ulothrix flacca, Blidingia minima, and Urospora penicilliformis, or widely within the boreal Pacific, such as Ulvaria splendens, Analipus japonica, Ptilota filicina, Neoptilota asplenioides, Nereis vexillosa, and Semibalanus cariosus, or only along the Asian coast, such as Anisogammarus locustoides, A. spasskii, Idotea ochotensis, I. gurjanovae, and Buccinum percrassum.

2. Features common to the middle and northern Kurils.

Many of these features are typical of the high-boreal biota: the absence of low-boreal Pelvetia babingtonii, sargassacean, and Phyllospadix iwatensis belts; the absence of subtropicboreal and low-boreal species, such as the crabs Hemigrapsus spp. and Cancer gibbosulus, the isopods Excirolana japonica and Cymodoce japonica, the chiton Ischnochiton hakodatensis, the gastropods Notoacmaea spp. and Batillaria cumingii, the seastar Lysastrosoma anthosticta, and many other species. Some common low-boreal species, such as Margarites pilsbryi, Epheria turrita, Strongylocentrotus intermedius, Laminaria japonica, and Kjellmaniella gyrata, are replaced by their high-boreal vicariants or ecological counterparts, such as Margarites helicina, Epherria porrecta, Strongylocentrotus polyacanthus, Laminaria longipes, and $L$. bongardiana. The brown algae Pleuropterum paradiseum and Cymathaere triplicata, the isopod Neastacilla littoralis, the gastropod Mitrella kobai, and the bivalve Mysella kurilensis litoralis, which are common to the middle and north Kurils, are also typical of the intertidal zone of the high-boreal Kuril province.

3. Although the intertidal biota of the middle Kurils has strong affinities to that of the northern Kurils, some essential differences exist between these two areas. First, there are many species that occur in the southern and northern Kurils but are absent from the middle Kurils, such as the polychaetes Eulalia viridis and Syllis fasciata (Khlebovitch, 1961), the gastropods Collisella spp. and Testudinalia scutum (Golikov \& Kussakin, 1962), pagurids, and the cirriped Chthamalus dalli (Kussakin, 1976). It is interesting that three common species of Collisella and two common species of Pagurus are found at Paramushir Island in the northern Kurils and in the southern Kurils but are absent from Urup Island to Onekotan Island. The authors once explained this phenomenon as due to the low summer sea temperature $\left(3^{\circ}-7^{\circ} \mathrm{C}\right)$ in the middle Kurils. Our recent visits to the shores of Urup, Ushishir, and Shiashkotan Island have confirmed these observations. On the contrary, some cold-water, high-boreal species, such as Cymathaere triplicata, Vilasina vernicosa, Modiolus phenax, Cucumaria vegae, and Eupentacta pseudoquinquesemita, flourish in the middle Kurils. Both the species composition and intertidal zonation at Ushishir and Shiashkotan Island are more similar to those at Urup (Kussakin et al., 1974) and Simushir Island (Kussakin, 1976) than to those at Paramushir Island (Kussakin et al., 1974). Therefore, the separation of the middle Kuril district within the Kuril province (Gulbin, 1974) is well-founded.

4. Some features peculiar to Yankich Island are noticeable, but most of them are encountered only in Kraternaya Bight, not on the open coasts. The characteristic disturbance of the usual zonal pattern and the uniqueness in species composition are apparently caused by gaso-hydrothermal vents and other forms of volcanic activity and are not attributable to usual physical factors such as temperature, salinity, and so on. It is, however, quite difficult to determine exactly how much influence these volcanic activities exert on the intertidal biota of Kraternaya Bight because there are no similar semi-enclosed bights lacking such activity in the middle Kurils. Brouton Bay at Simushir Island is the only semi-enclosed protected area comparable to Kraternaya Bight, but it is also a caldera with apparent 
volcanic activity.

Brouton Bay was visited by O. Kussakin in August, 1957. The temperature of the surface waters was about $13^{\circ} \mathrm{C}$, compared to $3.5^{-} 5^{\circ} \mathrm{C}$ in the open sea around this island. The shoreline in the inner part of this bay is formed of boulder-gravel and pebble-sandy beaches. Here and there a small issue of gaso-hydrothermal vents was observed. The substrate and mollusk shells were covered with rusty films. Four belts ranging from the lowest intertidal to the lower supra-littoral could be distinguished along this shore: 1 - an Alaria angusta belt with an admixture of Palmaria stenogona and other red algae; 2 - a rhodophycean belt with a predominance of Iridaea cornucopiae and Mastocarpus pacificus in the lower part and Halosaccion glandiforme in the upper part; 3 - a well-developed, mid-littoral Fucus evanescens belt partly spreading into the lower intertidal; 4 - an upper-littoral Littorina sitkana belt with Anisogammarus locustoides and Gnorimosphaeroma noblei beneath the stones. Pleuropterum paradiseum, Balanus crenatus, and Onchidoris bilamellata were not found. On the other hand, in the lowest part of the rocky intertidal, a narrow belt of the sea-grass Phyllospadix iwatensis, a low-boreal species, was found, representing its northern limit of distribution.

The most remarkable feature of the intertidal biota of Kraternaya Bight was dense populations of the white barnacle, Balanus crenatus. This widely distributed amphi-boreal species is common in the infra-littoral and lowest intertidal zones along south-east Kamchatka with a biomass up to $35 \mathrm{~kg} \mathrm{~m}^{-2}$ (List, 1989), but had not been yet recorded for the intertidal zone of the Kuril Islands. Kraternaya Bight represents the only exception and, furthermore, in this bight $B$. crenatus is a common species in the lower and middle intertidal subzones and is common not only on stones and shells of Nucella, but it also forms dense masses on the thalli of large brown and red algae, especially on Fucus evanescens. It is difficult for the authors to understand the factors affecting the presence of this barnacle in the bight and its larval ecology. Probably, a high biomass of plankton (up to $1 \mathrm{~g} \mathrm{~m}^{-3}$ ) in the bight (Zhirmunsky \& Tarasov, 1990) favours the flourishing of the sestonophagous Balanus crenatus and benefits the creation of a surplus larval pool. This pressure of an enormous larval pool and a lack of shore stones results in the settling of barnacles on algal thalli. This is an indirect influence of gaso-hydrothermal activity that favours the eutrophication of the bight.

The arrangement of Fucus evanescens, which may spread into the lower intertidal zone, and the settlement of Alaria on Fucus blades show lesser significant deviations from the typical zonation. Besides Balanus crenatus, in Kraternaya Bight the alariacean alga Pleuropterum paradiseum, the spionid polychaete Polydora vulcanica, the nudibranch Onchidoris bilamellata, the holothurian Psolus fabricii, and the sea urchin Strongylocentrotus droebachiensis are especially plentiful. Pleuropterum paradiseum is distributed from Urup Island to Alaid Island (Miyabe \& Nagai, 1933; Nagai, 1941), is an endemic species of the Kuril province. Onchidoris bilamellata is a widely distributed amphi-boreal species, but it had not been observed before anywhere in the intertidal zone of the Kuril Islands. Strongylocentrotus droebachiensis is also an amphi-boreal species. In Kraternaya Bight it forms isolated populations consisting only of small but mature specimens, and it is replaced outside the bight by the common high-boreal Pacific sea urchin, S. polyacanthus. Polydora vulcanica has so far been found only in Kraternaya Bight and is therefore an endemic species there. Some authors (Tarasov et al., 1988; Zhirmunsky \& Tarasov, 1990) also considered Psolus sp. as presumably a species new to science, and the bivalve Macoma lukini Kamenev, as endemic in Kraternaya Bight. But Kamenev (1989), describing his new species of bivalve, reported it as well from Brouton Bay at Simushir Island. Kafanov (1991) considered this species as a probable synonym of $M$. obliqua (Sowerby) from Pleistocene deposits in England. A large collection of Psolus spp. from the Kuril Islands deposited in the Zoological Institute (St.-Petersburg) needs further revision. A preliminary identification of 43 specimens from Kraternaya Bight allows us to conclude that this is the widely distributed amphi-boreal species Psolus fabricii 
(Smirnov, 1995).

It is very doubtful that independent species could arise in Kraternaya Bight during the 10 thousand years of its existence. However, the denial of the independent establishment of endemism in Kraternaya Bight can by no means wipe out the problem of high endemism of the shore biota of the middle Kurils, and discussion concerning the possible influence of volcanic activity on speciation is highly relevant. Actually, the volcanic middle Kurils constitute a unique region of the far-eastern seas of Russia. Just for laminarians and gastropods, five endemic genera are recognised: the three laminarian genera Costularia Ju. Petrov \& Gussarova, and Feditia Ju. Petrov \& Gussarova from Simushir Island, and the new genus Undariella Petrov \& Kussakin from Yankich Island; the gastropod genus Lacunitunica Golikov \& Gulbin and, in addition, the subgenus Neomargarites (Gussarova, 1975; Golikov \& Gulbin, 1978; Petrov \& Kussakin, 1996). If we add to these genera the alariacean genus Pleuropterum and the gastropod genus Corneobuccinum (Golikov \& Gulbin, 1977), which are endemic to the middle and northern Kurils, the resultants are even more impressive.

Tarasov with co-authors, already cited above, proclaimed a very high biomass as the second remarkable feature of the biota of Kraternaya Bight connected with volcanic activity. Population densities and biomasses of the intertidal communities within Kraternaya Bight are, in general, relatively but not extremely high. The maximum animal biomass in the intertidal zone occurs in the community dominated by the polychaete Polydora vulcanica (mean biomass $8.6 \mathrm{~kg} \mathrm{~m}^{-2}$, maximum biomass up to $18 \mathrm{~kg} \mathrm{~m}^{-2}$ ). The Polydora natrix community at Urup Island (total animal biomass $5640 \mathrm{~g} \mathrm{~m}^{-2}$ with Polydora at $4400 \mathrm{~g} \mathrm{~m}^{-2}$. Kussakin et al., 1974) has a similar mean biomass. The biomasses of other animals (240 to $6600 \mathrm{~g} \mathrm{~m}^{-2}$ ) and plants $\left(66 \mathrm{~g}\right.$ to $27 \mathrm{~kg} \mathrm{~m}^{-2}$ ) in the intertidal zone of Kraternaya Bight by no means exceed the ordinary values typical of the boreal sheltered or moderately protected littoral (Kussakin, 1963; Kussakin et al., 1974; Tarakanova, 1978).

On the whole, the influence of gaso-hydrothermal products results in the same picture of high biomass along with decreased species diversity as that observed under the influence of any other pollutant. In reality, we have observed extraordinarily large animal biomasses in places slightly or moderately polluted by waste products of fish or whale processing, e.g. the biomass of Littorina sitkana up to $15.5 \mathrm{~kg} \mathrm{~m}^{-2}$ and Semibalanus cariosus up to $22 \mathrm{~kg} \mathrm{~m}^{-2}$ in Kasatka Bay, Iturup Island (Kussakin et al., 1974).

\section{Acknowledgements}

The authors thank the following colleagues for kindly identifying the algae and some of the animals: Dr. I. Levenets, Algae; Dr. S. Chaplygina, Hydrozoa; Drs. A. Ozolinsh and E. Bagaveeva, Polychaeta; Dr. A. Kubanin, Bryozoa; Drs. G. Evseev and M. Ivanova, Bivalvia; Dr. T. Sokolovskaya, Pisces (Institute of Marine Biology, Vladivostok); Dr. V. Kudrjashov, Amphipoda (Far-East University, Vladivostok); Prof. V. Koltun, Spongia; Dr. B. Sirenko, Loricata; Dr. V. Romanov, Ascidia (Zoological Institute, St.-Petersburg). Their valuable help is highly appreciated. We give our sincere thanks to Dr. V. Tarasov for kind invitations and help during our surveys in the expeditions under his leadership. We are also very thankful to Ms. Irina Barsegova for help in preparing of the English manuscript.

The present publication was supported by the Russian Science Program "Biodiversity" project N2.3 45 and the Russian Foundation of Fundamental Research, project N 96-04-48076.

\section{References}

Gavrilenko, G.M., Bondarenko, V.I. \& Sazonov, A.P. 1989. Marine volcanological research in Kraternaya Bight. Biol. Mor., Vladivostok, 1989(3): 19-28. [In Russian with English sum- 
mary]

Golikov, A.N. \& Gulbin, V.V. 1977. Prosobranch gastropods of the Kurile Islands. II. Orders Hamiglossa-Homoestropha. In: O.G. Kussakin (ed.), Fauna of Coastal Zones of the Kurile Islands, Nauka Press, Moscow: 172-268. [In Russian]

Golikov, A.N. \& Gulbin, V.V. 1978. Prosobranch gastropods of the Kuril Islands. I. Orders Docoglossa-Entomostoma. In: O.G. Kussakin (ed.), Animals and Plants of the Shelf of the Kurile Islands, Nauka Press, Moscow: 159-223. [In Russian]

Golikov, A.N. \& Kussakin, O.G. 1962. Fauna and ecology of the shell-bearing prosobranchs (Gastropoda, Prosobranchia) in the intertidal zone of the Kurile Islands. Explor. Far East Seas USSR, 8: 248-346. [In Russian]

Gulbin, V.V. 1974. On the biogeographical demarcation of the upper zones of the Kurile shelf. In: A.N. Golikov (ed.), Hydrobiology and Biogeography of the Shelfes of Cold and Temperate Waters of the World Ocean, Nauka Press, Leningrad: 58-59. [In Russian]

Gussarova, I.S. 1975. Macrophyta zonae sublittoralis insularum Kurilensium (Iturup, Urup et Simushir). Novit. System. Plant. non vascularum, 12: 111-118. [In Russian; titles in Latin]

Kafanov, A.I. 1991. Bivalve mollusks of the shelf and continental slope of the North Pacific. Vladivostok. 1-198. [In Russian]

Kamenev, G.M. 1990. A new species of the genus Macoma (Bivalve, Tellinidae) from the Kraternaya Bay (Yankich Island, Kurile Islands). Zool. Zhurn., 69(3): 127-132. [In Russian with English summary]

Khlebovich, V.V. 1961. Polychaeta of the shelf of South Sakhalin and their ecology. Explor. Fauna Seas, 30(38): 72-224. [In Russian]

Kussakin, O.G. 1963. Materials for a quantitative description of the plants and animals of the Barents Sea Islands of the Kandalaksha State Reserve. Rep. Kandalaksha State Reserve, 4: 183-231. [In Russian with English summary]

Kussakin, O.G. 1976. Structure and distribution of the macrobenthos in the intertidal zone of the Simushir (Kuril Islands). In: O.G. Kussakin (ed.), Coastal Communities of the Far-Eastern Seas, Academy of Sciences of the USSR, Far East Science Center, Institute of Marine Biology, Vladivostok, Transactions, 6: 5-21. [In Russian with English summary]

Kussakin, O.G., Kudryashov, V.A., Tarakanova, T.F. \& Shornikov, E.I. 1974. The belt-forming flora-fauna communities from the intertidal zone of the Kurile Islands. In: O.G. Kussakin (ed.), Flora and Fauna of the Intertidal Zone of the Kurile Islands, Nauka Press, Novosibirsk: 5-75. [In Russian with English summary]

List of macrophytes and invertebrates of macrobenthos of Avacha Bay. 1989. In: O.G. Kussakin (ed.), Hydrobiological Investigations in the Avacha Bay, Vladivostok: 91-116.

Miyabe, K. \& Nagai, M. 1933. Laminariaceae of the Kurile Islands. Trans. Sapporo Nat. Hist. Soc., 13(2): $85-102$.

Nagai, M. 1941. Marine Algae of the Kurile Islands. Part 2. J. Fac. Agricult. Hokkaido Imp. Univ., 46(2): 139-310.

Petrov, Y.E. \& Kussakin, O.G. (in press). Undariella Kurilensis, new genus, new species of laminarian alga (Phaeophycota Laminariales, Alariaceae) from the intertidal zone of volcanic Yankich Island (middle Kurile Islands). Biol. Mor., Vladivostok, 23 (2).

Smirnov, A.V. 1995. On a Psolus species encountered in Kraternaya Bight (Ushishir Island, the Kurile Islands). Biol. Mor., Vladivostok, 21(1): 83-84. [In Russian with English summary]

Shulkin, V.M. 1989. Geochemistry of metals in the Kraternaya Bight ecosystem. Biol. Mor., Vladivostok, 1989(3): 29-36. [In Russian with English summary]

Stephenson, T.A. \& Stephenson, A. 1972. Life Between Tidemarks on Rocky Shores. Freeman, San Francisco, 1-425.

Tarakanova, T.F. 1978. The quantitative distribution of intertidal macrobenthos of the Bering Island (Commander Islands). In: O.G. Kussakin (ed.), The Intertidal Zone of the Bering Sea and South-eastern Kamchatka, Nauka Press, Moscow: 63-77. [In Russian with English summary]

Tarasov, V.G., Propp, M.V., Propp, L.N., Zhirmunsky, A.V., Namsaraev, B.B., Gorlenko, V.M. \& Starynin, D.A. 1990. Shallow-water gasohydrothermal vents of Ushishir Volcano and the 
ecosystem of Kraternaya Bight (the Kurile Islands). P.S.Z.N.I.: Marine Ecology, 11(1): 1-23.

Tarasov, V.G., Propp, M.V., Zhirmunsky, A.V. \& Kostina, E.E. 1988. Coastal volcanism and specific ecosystems in the north-western Pacific. Pacific Annual, Vladivostok: 115-120.

Zhirmunsky, A.V. \& Tarasov, V.G. 1990. Unusual marine ecosystem in the flooded crater of Ushishir volcano. Marine Ecology, Progress Series, 65: 95-102.

Zinova, A.D. \& Perestenko, L.P. 1974. A list of intertidal algae of the Kurile Islands. In: O.G. Kussakin (ed.), Flora and Fauna of the Intertidal Zone of the Kurile Islands, Nauka Press, Novosibirsk: 332-340. [In Russian with English summary] 


\section{Appendix Table}

\section{List of Macrobenthic Species of the Intertidal Zone of Yankich Island}

Since the middle Kuril Islands were poorly represented in our list of intertidal animals (Kussakin et al., 1974; Kussakin, 1976) and a list of macrophytes (Zinova \& Perestenko, 1974) from the intertidal zone of the Kuril Islands, we consider it useful to give the complete list of plants and animals collected by the authors from the intertidal zone of Yankich Island.

\begin{tabular}{|c|c|c|c|c|}
\hline & \multicolumn{4}{|c|}{ Areas and Transects } \\
\hline Species & $\begin{array}{l}\text { Inner part: near } \\
\text { hydrosolfatar } \\
\text { field (Transects } \\
\text { 14-17) }\end{array}$ & $\begin{array}{l}\text { Middle part of } \\
\text { bight (Tran- } \\
\text { sects 8-13) }\end{array}$ & $\begin{array}{l}\text { Entrance to } \\
\text { bight (Tran- } \\
\text { sects } 3-6)\end{array}$ & $\begin{array}{l}\text { Open coast } \\
\text { (Transects } \\
1 \& 2 \text { ) }\end{array}$ \\
\hline
\end{tabular}

\section{PLANTS}

Division CHLOROPHYCOTA

Class ULOTRICHOPHYCEAE

Order ULOTRICHALES

Family Ulotrichaceae

Ulothrix flacca (Dillw) Thurner

U. pseudoflacca Wille

Order ACROSIPHONALES

Family Acrosiphonaceae

Acrosiphonia duriuscula (Ruprecht) Yendo

A. saxatilis (Rupr.) Vinogradova

Urospora penicilliformis (Roth) Areschough

Order ULVALES

Family Monostromataceae

Monostroma grevillei (Thurner) Wittrock

Kornmannia zostericola (Tilden) Bliding

Blidingia minima (Nageli et Kutzing) Kylin

Family Ulvaceae

Ulvaria splendens Ruprecht

Class SIPHONOPHYCEAE

Order SIPHONALES

Family Codiaceae

Codium ritteri Setchell et Gardner

Division PHAEOPHYCOTA

Class PHAEOSPOROPHYCEAE

Order ECTOCARPALES

Family Ectocarpaceae

Pilayella litoralis (Linnaeus) Kjellman

Ectocarpus confervoides (Roth) Le Jols

Order RALFSIALES

Family Ralfsiaceae

Analipus japonicus (Harvey) Wynne

Ralfsia fungiformis (Gunn.) Setchell et Gardner

Order DICTYOSIPHONALES

Family Punctariaceae

Punctaria plantaginea (Roth) Greville

Family Asperococcaceae Melanosiphon intestinalis (Saund.) Wynne f. complanata (Woron) Wynne

Family Dictyosiphonaceae Coilodesme fucicola (Yendo) Nagai

Order SCYTOSIPHONALES

Family Scytosiphonaceae Colpomenia peregrina (Sauvageau) Hamel

Order DESMARESTIALES

Family Desmarestiaceae

Desmarestia aculeata (Linnaeus) Lamouroux

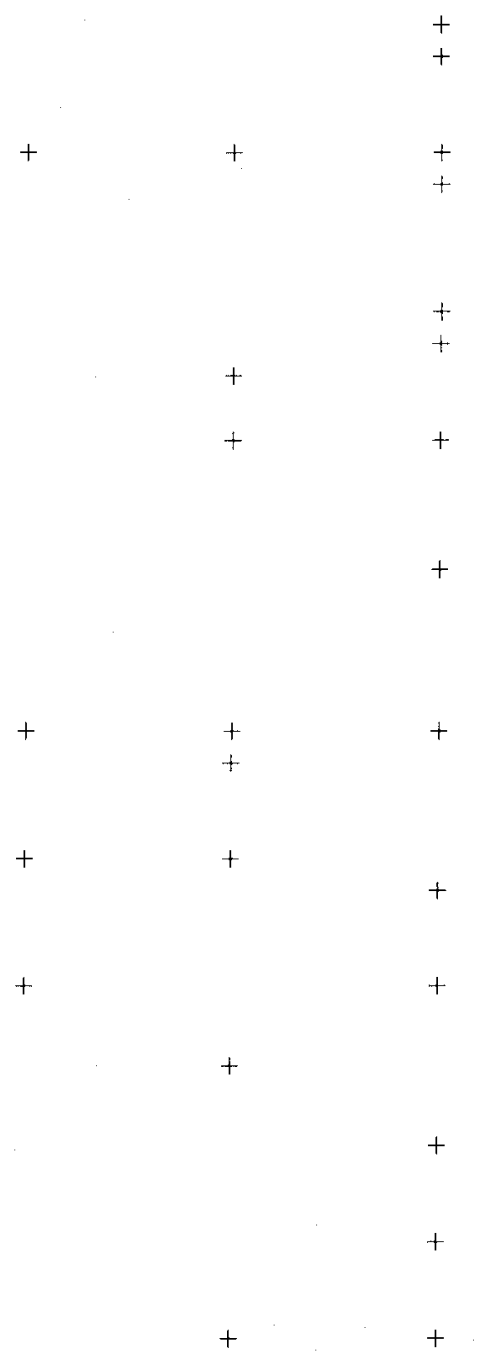


Order LAMINARIALES

Family Laminariaceae

Laminaria longipes Bory f. angustifolia (Postels et Ruprecht) Miyabe et Nagai in Nagai

L. bongardiana Postels et Ruprecht

Arthrothamnus kurilensis Ruprecht

Thalassiophyllum clathrus (Gmelin) Postels et Ruprecht

Family Alariaceae

A laria marginata Postels et Ruprecht

A. angusta Kjellm. emend. Yu. Petrov

Alaria sp.

Pleuropterum paradiseum Miyabe et Nagai in Nagai

Undariella kurilensis Petrov et Kussakin

Order FUCALES

Family Fucaceae

Fucus evanescens C. Agardh

Division RHODOPHYCOTA

Class BANGIOPHYCEAE

Order BANGIALES

Family Bangiaceae

Porphyra tasa (Yendo) Ueda

?P. aff, umbilicalis

Class FLORIDEOPHYCEAE

Order CRYPTONEMIALES

Family Dumontiaceae

Constantinea rosa-marina (Gmelin) Postels et Ruprecht

Family Hildenbrandtiaceae

Hildenbrandtia prototypus Nardo

Family Corallinaceae

Clathromorphum loculosum (Kjellman)

Titanoderma sp.

Family Kallymeniaceae

Callophyllis rhynchocarpa Ruprecht

Family Crossocarpaceae

Velatocarpus pustulosus Perestenko

Order GIGARTINALES

Family Nemastomataceae

Schizymenia pacifica Kylin

Family Gigartinaceae

Mastocarpus pacificus (Kjellman) Perestenko

Iridaea comucopiae Postels et Ruprecht

Order RHODYMENIALES

Family Rhodymeniaceae

Rhodymenia pertusa (Postels et Ruprecht) J. Agardh

Palmaria stenogona (Perestenko) Perestenko

Halosaccion glandiforme (Gmelin) Ruprecht

Order CERAMIALES

Family Ceramiaceae

Ptilota filicina J. Agardh

Neoptilota asplenioides (Turner) Kylin

Family Delesseriaceae

Congregatocarpus pacificus (Yamada)

Mikami

Micamiella sp.

Family Rhodomelaceae

Symphyocladia marchantioides

(Harvey) Falkenb.

Polysiphonia morrowii Harvey

? Odontalia floccosa (Esp.) Falkenberg 
Rhodomela sibirica A. Zinova et Vinogradova

?Neorhodomela aculeata Masuda

Kingdom ANIMALIA

PHYLUM SPONGIA

Class CALCAREA

Order SYCETTIDA

Family Sycettidae

Sycon ensiferum Denoby

$+$

$+$

$+$

$+$

\section{$+$}

$+$

$+$

$+$

$+$

$+$
S. arctica (Haeckel)

S. utriculus (Schmidt)

Family Grantidae

Leucandra valida Lambe

Class DEMOSPONGIA

Order POECILOSCLERIDA

Family Myxillidae

Lissodendoryx amaknekensis (Lambe)

Order HALICHONDRIDA

Family Halichondriidae

Halichondria panicea (Pallas)

Order HAPLOSCLERIDA

Family Haliclonidae

Haliclona sp.

PHYLUM CNIDARIA

Class HYDROZOA

Order LEPTOLIDA

Family Corynidae Coryne pusilla Gaertner

Family Sertulariidae

Sertularella pinnata Clark

Abietinaria inconstans (Clark)

A. filicula filicula (Ellis et Solander)

Order THECAPHORA

Family Bonneviellidae

Bonneviella regia (Nutting)

Class SCYPHOZOA

Order STAUROMEDUSA

Family Haliclystidae

Haliclystus steinegeri Kishinoye

Class ANTHOZOA

Order ACTINIARIA

Family Condylanthidae

Charisea saxicola Torrey

Family Actiniidae

Cnidopus japonicus (Verrill)

Epiactis arctica (Verrill)

Bunodactis sp.

Family Metridiidae

Metridium senile fimbriatum Verrill

PHYLUM NEMERTINI

Class ENOPLA

Order HOPLONEMERTINI

Family Emplectonematidae

Paranemertes peregrina Loe

Emplectonematidae gen sp.

Family Tetrastematidae

Antarctonemertes (Kurileonemertes) sp.

Family Amphiporidae

Amphiporus fuscosparus Korotk.

$+$

$+$

$+$

$+$

$+$

PHYLUM ANNELIDA

Class POLYCHAETA

Order PHYLLODOCIDA

Family Phyllodocidae 
Phyllodoce (Anaitides) groenlandica Oersted

Phyllodoce sp.

Eteone longa (Fabricius)

? Eumida minuta (Ditlevsen)

Family Polynoidae

Lagisca rarispina (Sars)

Harmothoe imbricata Linné

Family Chrysopetalidae

Dysponetus pygmaeus (Levinsen)

Family Syllidae

Typosyllis ehlersioides japonica Buzhinskaja

T. pulchra occidentalis Buzhinskaja

Typosyllis sp.

Exogone gemmifera Pagenstecher

Family Nereidae

Nereis vexillosa Grube

$N$. pelagica Linne

Order SPINTHERIDA

Family Spintheridae

Spinther hystrix Uschakov

Order EUNICIDA

Family Eunicidae

Lumbrineris japonica (Morenzeller)

Order ORBINIIDA

Family Orbiniidae

Naineris quadricuspida (Fabricius)

N. jacutica Annenkova

Orbiniella nuda Hobson

Order SPIONIDA

Family Spionidae

Microspio sp.

Polydora vulcanica Radashevski

Boccardia sp.

Nerine sp.

Order CIRRATULIDA

Family Cirratulidae

Cirratulus wladislavi Buzhinskaja

Order FLABELLIGERIDA

Family Flabelligeridae

Flabelligera affinis Sars

Order CAPITELLIDA

Family Capitellidae

Capitella capitata (Fabricius)

Family Arenicolidae

Abarenicola vagabunda oceanica Healy et Wells A rachniomaldane vincenti Langerhans

Family Maldanidae

Nicomache sp.

Order TEREBELLIDA

Family Terebellidae

Terebella ehrenbergi Grube

Amphitrite cirrata Müller

Order SABELLIDA

Family Sabellidae

Amphiglena pacifica (Annenkova)

A. marita Chlebovitsch

Asabellides sibirica (Wirén)

Potamilla torelli Malmgren

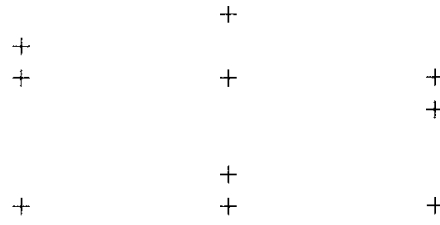

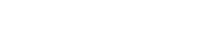

$+$

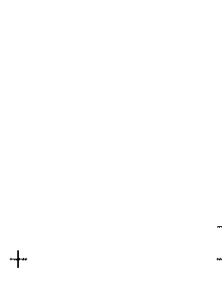

\begin{tabular}{|c|c|}
\hline & + \\
\hline & $\begin{array}{l}+ \\
+\end{array}$ \\
\hline+ & t \\
\hline & + \\
\hline & + \\
\hline+ & + \\
\hline+ & + \\
\hline+ & \\
\hline+ & + \\
\hline
\end{tabular}

Class ECHIURIDA

Order ECHIUROINEA

Family Bonelliidae

Bonellia sp.

PHYLUM ARTHROPODA 
Class CRUST ACEA

Subclass COPEPODOIDEA

Order THORACICA

Family Balanidae

Balanus crenatus Brugière

Semibalanus cariosus (Pallas)

$+$

Subclass MALACOSTRACA

Order LEPTOSTRACA

Family Nebaliidae

Nebalia bipes (Fabricius)

Order DECAPODA

Family LITHODIDAE

Hapalogaster grebnitzkii Schalfeev

Order AMPHIPODA

Family Ampithoidae

Ampithoe djakonovi Gurjanova

A. volki Gurjanova

A. eoa Bruggen

A. mea Gurjanova

Ampithoe sp.

Family Anisogammaridae

Anisogammarus (Eogammarus)

locustoides (Brandt)

A. (Spinulogammarus) spasskii (Bulycheva)

A. (Spinulogammarus) ochotensis (Brandt)

Family Calliopiidae

Paracalliopiella pacifica

Tzvetkova et Kudrjaschov

Family Corophiidae

Corophium steinegeri Gurjanova

Corophium sp.

Paracerapus polutovi (Gurjanova)

Family Hyalidae

Allorchestes malleolus Stebbing

A. carinata Iwasa

Parallorchestes ochotensis (Brandt)

Family Ischyroceridae

Ischyrocerus anguipes Krфyer

I. chamissoi Gurjanova

I. dezhnevi Gurjanova

I. tzvetkovae Kudrjaschov

I. krascheninnikovi Gurjanova

?. pachtusovi Gurjanova

Ischyrocerus sp.

Jassa oclairi Conlan

Family Lysianassidae

Anonyx affinis Ohlin

A. japonicus Gurjanova

Orchomenella japonica Gurjanova

Stomacontion sp.

Lepidopecreum sp.

Family Melitidae Melita sp.

Family Phoxocephalidae

Paraphoxus longirostris (Gurjanova)

$P$. robusta (Gurjanova)

Family Pontogeneiidae

Pontogeneia makarovi (Gurjanova)

Pontogeneia sp.

Tethygeneia rostrata (Gurjanova)

Family Pleustidae

Pleustes behningi (Gurjanova)

Pleusymtes sp.
$+$

$+$

$+$

$+$

$+$

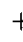

$+$

$+$

+
+

$+$

$+$

$+$

$+$

$+$

$+$

$+$

$+$

$+$

$+\quad+$

$+$

$+$

$+$

$+2$

$+$

$+$

$+$

$+$

$+$

$+$

$+$

$+$

$+$

$+$

$+$

$+$ 
Sympleustes glaber (Boeck)

Family Stenothoidae

Mesostenothoides slastnikovi (Gurjanova)

Family Talitridae

Talorchestia crassicornis Derzhavin

Family Caprellidae

Caprella parapaulina Vassilenko

C. cristibranchium Mayer

C. distalis Mayer

C. laeviuscula Mayer

Order ISOPODA

Family Sphaeromatidae

Gnorimosphaeroma noblei Menzies

Family Idoteidae

Idotea gurjanovae Kussakin

I. aleutica Gurjanova

PHYLUM MOLLUSCA

Class POLY PLACOPHORA

Subclass LORICATA

Order LEPIDOPLEURIDA

Family Leptochitonidae

Leptochiton assimilis (Thiele)

Order CHITONIDA

Family Lepidochitonidae

Spongioradsia aleutica (Dall)

Yuvenichiton albocinnamomensis Sirenko

Mucichiton grandispina Sirenko

Family Tonicellidae

Tonicella beringensis beringensis

Yakovleva

$T$. submarmorea Middendorff

Family Schizoplacidae

Schizoplax brandtii (Middendorff)

Family Mopaliidae

Placiphorella borealis Pilsbry

Class GASTROPODA

Subclass PECTINIBRANCHIA

Order ANISOBRANCHIA

Family Trochidae

Margarites helicina (Phipps)

Order DISCOPODEA

Family Lacunidae

Lacuna minor (Dall)

Epheria divaricata (Fabricius)

Family Littorinidae

Littorina sitkana Philippi

Family Falsicingulidae

Falsicingula sp.

Order ECHINOSPIRIDA

Family Velutinidae

Cartilagovelutina beringensis (Derjugin)

Limneria (Conivelutina) prolongata

(Carpenter)

Order HAMIGLOSSA

Family Pyrenidae

Astyris kobai Golikov et Kussakin

Family Buccinidae

Volutharpa ampullacea (Middendorff)

Buccinum baeri (Middendorff)

$+$

+
+

$+$

$+$

$+$

$+$

$+$

$+$

$+$

$+$

$+$

Family Thaididae

Nucella freycinettii (Deshayes)

Subclass OPISTHOBRANCHIA

Order NUDIBRANCHIA 
Family Onchidorididae

Onchidoris bilamellata Linné

Family Aeolididae

Aeolidia papillosa Linné

Class BIVALVIA

Order MYTILIDA

Family Mytilidaé Modiolus phenax (Dall)

Vilasina vernicosa (Middendorff)

Order LUCINIDA

Family Turtoniidae Turtonia minuta (Fabricius)

Order ADAPEDONTA

Family Hiatellidae

Hiatella arctica (Linné)

\section{PHYLUM BRYOZOA}

Class STENOLAEMATA

Order TUBULIPORIDA

Family Crisiidae

Crisia eburnea (Linné)

Class EURYSTOMATA

Order STENOSTOMIDA

Family Flustrellidridae

Flustrellidra conriculata (Smith)

Order FLUSTRIIDA

Family Flustriidae

Carbasea nordenskjoldii (Kluge)

Order BUGULIDA

Family Buguliidae

Dendrobeania murrayana (Johnston)

D. levinseni (Kluge)

Order CELLEPORIDA

Family Hippothoidae Celleporella hyalina (Linnê)

PHYLUM BRACHIOPODA

Class ARTICULATA

Order TEREBRATULIDA

Family Dallinidae

Diestothyris frontalis (Middendorff)

PHYLUM ECHINODERMATA

Class HOLOTHUROIDEA

Order DENDROCHIROTA

Family Cucumariidae Cucumaria vegae Theel

Eupentacta pseudoquinquesemita Deichmann

Family Psolidae

Psolus fabricii Düben et Koren

Class ASTEROIDEA

Order SPINULOSA

Family Echinasteridae

Henricia sp. (3)

Order FORCIPULATA

Family Asteriidae

Leptasterias hirsuta Djakonov

L. alaskensis asiatica Fischer

L. camtschatica (Brandt)

Class ECHINOIDEA

Order CAMARODONTA

Family Strongylocentrotidae

Strongylocentrotus droebachiensis Müiller

PHYLUM CHORDATA

Class ASCIDIACEAE

Order APLOUSOBRANCHIA 
Family Polyclinidae

Amaroucium sp. 1 (sp. n.?)

Amaroucium sp. 2

Order PHLEBOBRANCHIA

Family Ascidiidae

Ascidia callosa Stimpson

Order STYELIDAE

Family Styelidae

Styela coriaceae (Alder et Hancock)

Dendrodoa aggregata (Rathke)

Class TELEOSTOMI

Order PERCIFORMES

Family Stichaeidae

Ascoldia variegata Knipowich et Soldatov

Family Zoarcidae

Knusenstemiella $\mathrm{sp}$.

Order SCORPAENIFORMES

Family Cottidae

Myoxocephalus stelleri Tilesius

M. polyacanthocephalus (Pallas)

$M$. brandti (Steindachner)

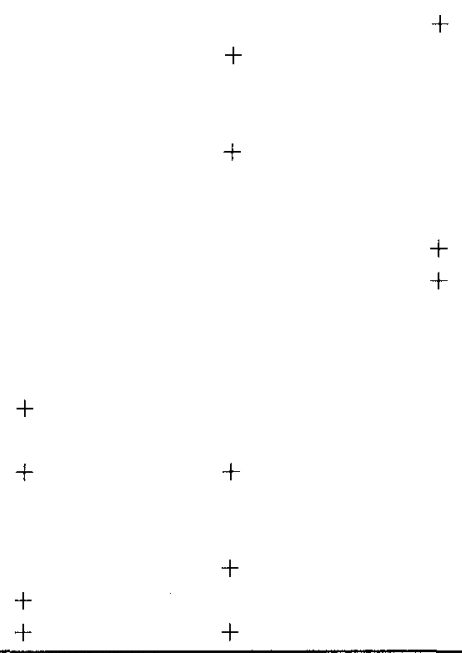

